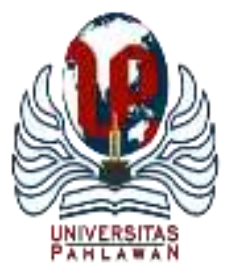

Edukatif : Jurnal Ilmu Pendidikan Volume 4 Nomor 1 Tahun 2022 Halm 572 - 581 EDUKATIF: JURNAL ILMU PENDIDIKAN

Research \& Learning in Education

https://edukatif.org/index.php/edukatif/index

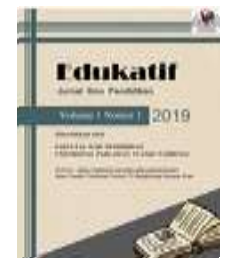

\title{
Penerapan Model Pembelajaran Kooperatif Tipe Make A Match untuk Meningkatkan Hasil Belajar Biologi
}

\author{
Tri Suwarno Handoko Noviyanto ${ }^{1 凶}$, Baiq Hana Susanti ${ }^{2}$, Siti Khairunnisa ${ }^{3}$ \\ UIN Syarif Hidayatullah Jakarta, Indonesia ${ }^{1,2}$, MTs Jam'iyyatul Khair, Indonesia ${ }^{3}$ \\ E-mail : trisu.hn@uinjkt.ac.id ${ }^{1}, \underline{\text { baiq.hana@ uinjkt.ac.id }}^{2}, \underline{\text { sitianis.kh@ gmail.com }}^{3}$
}

\begin{abstract}
Abstrak
Penelitian ini bertujuan untuk meningkatkan hasil belajar biologi melalui model pembelajaran kooperatif tipe make a match. Penelitian ini dilakukan di MTs Jam'iyyatul Khair. Metode penelitian yang digunakan adalah penelitian tindakan kelas, dengan tahapan perencanaan, tindakan, observasi dan refleksi. Sampel penelitian berjumlah 17 siswa, yang terdiri atas 7 siswa laki-laki dan 10 siswa perempuan. Instrumen penelitian yang digunakan adalah tes hasil belajar yang berupa tes objektif berbentuk pilihan ganda yang telah diuji validitas dan reliabilitasnya. Analisis data dengan menggunakan rumus Gain-Ternormalisasi (N-Gain). Adapun keberhasilan dalam belajar dengan merujuk pada indikator pencapaian hasil (IPH) $\geq 80 \%$ dan nilai ketuntasan minimal $(\mathrm{KKM}) \geq 70$. Hasil penelitian ini memperlihatkan bahwa rata-rata hasil belajar biologi pada siklus 1 dan siklus 2 berturut-turut adalah 67,20 dan 83,53. Dari 17 siswa, pencapaian KKM mengalami peningkatan menjadi 15 siswa $(88,24 \%)$ pada siklus 2 , dibandingkan dengan siklus 1 sebanyak 10 siswa $(58,82 \%)$. Hal tersebut menunjukkan bahwa hasil belajar biologi mengalami peningkatan yang signifikan dibandingkan pada siklus 1 . Dengan demikian, siklus 2 sudah memenuhi indikator pencapaian hasil (IPH), karena persentase kelas di atas $80 \%$.
\end{abstract}

Kata Kunci: model pembelajaran kooperatif, make a match, hasil belajar.

\section{Abstract}

The aim of this research is to improve biology learning outcome through cooperative learning model of make a match. This research was conducted at MTs Jam'iyyatul Khair. The research method was used classroom action research, through stages of planning, action, observation and reflection. The research sample were 17 students, consisted of 7 male students and 10 female students. Multiple choice objective test that has been tested its validity and reliability used as research instrument. The data analysis used Normalized-Gain ( $N$ Gain). The success in learning referred to the result achievement indicators (IPH) $\geq 80 \%$ and the minimum completeness criteria $(\mathrm{KKM}) \geq 70$. This study shown that average of biology learning outcome in cycle 1 and cycle 2 are respectively 67,20 and 83,53. From 17 students, the achievement of KKM increased to 15 students $(88.24 \%)$ in cycle 2 , compared with cycle 1 of 10 students $(58.82 \%)$. This result indicates that biology learning outcome increased significantly compared to cycle 1. Thus, cycle 2 has fulfilled the result achievement indicators (IPH), because percentage of grade above $80 \%$.

Keywords: cooperative learning model, make a match, learning outcome

Copyright (c) 2022 Tri Suwarno Handoko Noviyanto, Baiq Hana Susanti, Siti Khairunnisa $\triangle$ Corresponding author

Email : trisu.hn@uinjkt.ac.id

DOI $\quad$ : https://doi.org/10.31004/edukatif.v4i1.1855

ISSN 2656-8063 (Media Cetak)

ISSN 2656-8071 (Media Online) 
573 Penerapan Model Pembelajaran Kooperatif Tipe Make A Match untuk Meningkatkan Hasil Belajar Biologi - Tri Suwarno Handoko Noviyanto, Baiq Hana Susanti, Siti Khairunnisa

DOI: https://doi.org/10.31004/edukatif.v4i1.1855

\section{PENDAHULUAN}

Program Millennium Development Goals telah direncanakan semenjak tahun 2015. Millennium Development Goals merupakan era pasar bebas atau bisa juga disebut era globalisasi, yang merupakan era persaingan mutu dan kualitas. Dalam hal ini, siapa yang berkualitas maka akan mampu mempertahankan eksistensinya (Mulyasa, 2008). Oleh karenanya, pembangunan sumber daya manusia berkualitas merupakan suatu keharusan yang perlu dilakukan dari sekarang. Berhubungan dengan peningkatan sumber daya manusia, faktor utama yang harus diperbaiki adalah sektor pendidikan.

Di sekolah, keberhasilan suatu pendidikan tidak terlepas dari peran kepala sekolah dan unsur kependidikan lainnya dalam menerjemahkan rancangan kurikulum dengan pihak terkait, memilih metode yang sesuai untuk ketercapaian ketuntasan belajar yang mana bertujuan untuk menghasilkan siswa yang berkualitas. Oleh karenanya perencanaan yang matang perlu disusun dan dipersiapkan sebaik mungkin (Sabariah, 2022). Tentu saja keterlibatan kepala sekolah untuk penyelenggaraan program ini dengan cara menyusun kebijakan yang dapat mengayomi seluruh stake holder yang ada di sekolah sehingga pelaksanaan pendidikan dapat berjalan secara baik (Devi \& Subiyantoro, 2021).

Terlepas dari persiapan sekolah untuk menyukseskan kegiatan pembelajaran, ada beberapa permasalahan yang sudah terjadi dan berlangsung lama dihadapi dunia pendidikan saat ini, salah satunya adalah kurang optimalnya proses pembelajaran di kelas. Dalam aktivitasnya, terkadang siswa kurang didorong untuk mengembangkan kemampuan berpikir. Akan tetapi, guru menuntut siswa untuk mampu menguasai pelajaran secara tuntas. Bercermin dari hal tersebut, pembelajaran yang terjadi di kelas pada akhirnya hanya menuntut siswa untuk menghafal materi pelajaran, tanpa dituntut untuk memahami materi yang diingatnya itu dengan dihubungkan dalam kehidupan sehari-hari.

Berbicara kurang optimalnya pembelajaran di kelas, proses pembelajaran yang cenderung monoton menyebabkan siswa merasa bosan mengikuti kegiatan belajar. Minat belajar siswa menurun dan secara tidak langsung nilai siswa di bawah standar kriteria ketuntusan minimal (KKM). Masalah yang demikian akan menjadi masalah yang besar jika guru tidak segera memperbaikinya.

Selain itu, lemahnya proses pembelajaran di dalam kelas juga disebabkan oleh adanya beberapa siswa yang bertindak sebagai pembuat masalah. Terkadang, siswa yang demikian dapat mengganggu suasana kelas menjadi tidak kondusif selama berlangsungnya proses belajar mengajar. Kelas yang demikian perlu ditindaklanjuti agar proses pembelajaran dapat berjalan dengan baik, dan siswa yang bertindak sebagai pembuats masalah perlu diarahkan dengan cara melibatkan siswa dalam setiap aktivitas belajar.

Agar permasalahan yang timbul dapat diatasi maka tindakan supervisi perlu dilakukan. Adapun sasaran dari supervisi pendidikan adalah kegiatan belajar mengajar yang ditujukan untuk meningkatkan mutu dan proses pembelajaran, yang mana didalamnya terlibat guru, siswa, kurikulum, sumber belajar, termasuk model pembelajaran yang diimplementasikan di kelas (Wandra, Marsyidin, \& Rifma, 2021)

Mengingat pentingnya perbaikan proses belajar mengajar di kelas, seorang guru perlu menerapkan model pembelajaran yang dapat membuat siswa menjadi lebih produktif di kelasnya. Berkaitan dengan pelajaran IPA, khususnya materi biologi, siswa cenderung malas dan bosan untuk mempelajari materi tersebut, dikarenakan banyak sekali konsep yang harus dipelajari. Salah satu model pembelajaran yang dapat menumbuhkan suasana kelas menjadi lebih hidup dengan menggunakan model pembelajaran kooperatif tipe make a match. Model pembelajaran kooperatif ini dapat menstimulus siswa untuk lebih semangat dalam belajar.

Dengan gambaran permasalahan yang ada, maka penelitian ini dirumuskan sebagai berikut: "Apakah penerapan model pembelajaran kooperatif tipe make a match dapat meningkatkan hasil belajar biologi?" Dari rencana pemecahan masalah yang telah dirumuskan, maka tujuan penelitian ini adalah untuk meningkatkan hasil belajar biologi melalui model pembelajaran kooperatif tipe make a match. 
Slavin menjelaskan bahwa pembelajaran kooperatif adalah sebuah strategi belajar, yang mana siswa dalam satu kelompok saling bekerja sama dan membantu untuk mempelajari suatu bahan pelajaran, mengerjakan tugas serta melakukan berbagai kegiatan lain dengan tujuan mencapai prestasi belajar yang lebih baik (Zulfiani, Feronika, \& Suartini, 2009). Pembelajaran kooperatif berbeda dengan strategi pembelajaran yang lain. Perbedaan tersebut dapat dilihat dari proses pembelajaran yang lebih menekankan kepada proses kerja sama dalam kelompok. Berdasarkan proses pembelajarannya, maka pembelajaran kooperatif memiliki karakteristik sebagai berikut (Sanjaya, 2008):

1. Pembelajaran secara tim

Pembelajaran kooperatif adalah pembelajaran secara kelompok. Semua anggota kelompok harus saling membantu untuk mencapai tujuan pembelajaran. Dalam praktiknya, setiap kelompok harus bersifat heterogen, artinya bahwa dalam suatu kelompok harus terdiri atas anggota yang memiliki kemampuan akademik, jenis kelamin, dan latar belakang sosial yang berbeda. Hal ini dimaksudkan agar setiap anggota kelompok dapat saling memberikan pengalaman, sehingga diharapkan setiap anggota dapat memberikan kontribusi terhadap keberhasilan kelompoknya.

2. Kemauan untuk bekerja sama

Keberhasilan pembelajaran kooperatif ditentukan oleh keberhasilan secara kelompok. Oleh sebab itu, prinsip bekerja sama perlu ditekankan dalam proses pembelajaran kooperatif. Setiap anggota kelompok bukan saja harus diatur tugas dan tanggung jawab masing-masing, akan tetapi juga ditanamkan perlunya sikap saling membantu. Hal ini terlihat dalam kegiatan pembelajaran di kelas, dimana siswa yang pintar membantu siswa yang kurang pintar.

3. Keterampilan bekerja sama

Kemauan untuk bekerja sama dipraktikkan melalui aktivitas dan kegiatan yang tergambarkan dalam keterampilan bekerja sama. Dengan demikian, siswa perlu didorong untuk mau berinteraksi dan berkomunikasi dengan anggota lain. Siswa perlu dibantu mengatasi berbagai hambatan dalam berinteraksi dan berkomunikasi, sehingga setiap siswa dapat menyampaikan ide, mengemukakan pendapat, dan memberikan kontribusi untuk keberhasilan kelompok.

Berdasarkan karakteristik model pembelajaran tersebut, maka setiap siswa harus memiliki kesadaran untuk ikut serta berpartisipasi dalam kelompok. Keberhasilan atau kegagalan yang diperoleh kelompok sangat dipengaruhi oleh kinerja setiap anggota yang tergabung dalam kelompok tersebut. Untuk itu, sangat diperlukan interaksi dan kerja sama yang baik antar anggota kelompok, agar kegiatan pembelajaran terasa manfaatnya oleh setiap anggota.

Selain itu pembelajaran yang baik bukan hanya mengacu terhadap apa yang siswa peroleh setelah belajar, melainkan juga proses yang dibangun selama aktivitas berlangsung. Siswa tidak merasa dijejali dengan konten pengetahuan yang banyak, tetapi siswa sendiri yang mencoba memahami apa yang mereka pelajari. Untuk itulah rekan sejawat sangat berperan untuk menciptakan harmonisasi pengetahuan yang sedang dipelajari, dengan menerapkan proses belajar melalui model pembelajaran kooperatif tipe make a match (Ramadhani, 2021).

Pembelajaran kooperatif tipe make a match sebagai sebuah model pembelajaran yang menekankan siswa untuk berpikir dalam mencari pasangan suatu konsep. Salah satu keunggulan model pembelajaran ini adalah siswa mencari pasangan konsep sambil mempelajari materi yang sedang diajarkan oleh gurunya (Situmorang, Purba, \& Gultom, 2021). Dalam pembelajaran kooperatif tipe make a match, langkah-langkah kegiatan dapat dijelaskan sebagai berikut (Riyanto, 2009): 
575 Penerapan Model Pembelajaran Kooperatif Tipe Make A Match untuk Meningkatkan Hasil Belajar Biologi - Tri Suwarno Handoko Noviyanto, Baiq Hana Susanti, Siti Khairunnisa

DOI: https://doi.org/10.31004/edukatif.v4i1.1855

1. Guru membuat kartu-kartu yang berpasangan, terdiri atas kartu pertanyaan dan kartu jawaban seperti pada gambar 1.
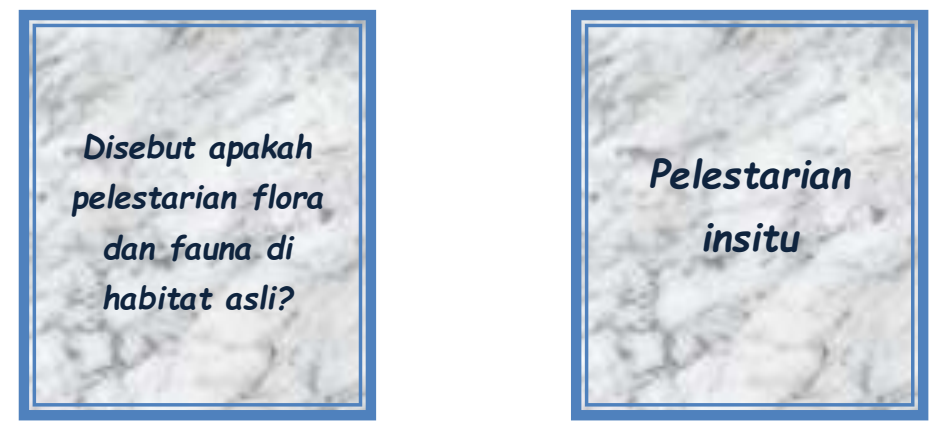

Gambar 1. Gambar Kartu Make a Match

2. Setiap siswa ada yang memegang kartu pertanyaan dan kartu jawaban.

3. Siswa saling memperlihatkan kartu yang didapatkannya kepada siswa yang lain.

4. Siswa mencari pasangan yang sesuai dengan kartu yang didapatkannya.

5. Siswa berdiskusi sebentar untuk menjelaskan pasangan kartu tersebut.

Model pembelajaran kooperatif tipe make a match membantu siswa menjadi lebih aktif dalam kegiatan belajar di kelas, sehingga secara tidak langsung hasil belajar siswa akan meningkat. Hasil belajar merupakan realisasi pengembangan kemampuan yang dimiliki oleh seorang siswa. Penguasaan hasil belajar dapat ditunjukkan dari perubahan perilakunya, baik dalam bentuk penguasaan pengetahuan, keterampilan motorik serta sikap siswa (Sukmadinata, 2007). Adapun ketika siswa mempelajari biologi, siswa dapat secara aktif membangun pengetahuannya melalui beragam aktivitas yang bermakna (Budiarti, Suparmi, Sarwanto, \& Harjana, 2020).

Penggunaan kartu dalam aktivitas belajar dapat disenangi oleh siswa (Hadiyanti, 2021). Dengan melibatkan siswa dalam kegiatan belajar merupakan suatu cara bagaimana siswa dapat membangun pengetahuannya sendiri terkait materi yang sedang siswa pelajari. Dengan menerapkan kooperatif tipe make a match, siswa tidak hanya memperoleh pengetahuan dari guru semata, melainkan dari teman sebaya. Adanya interaksi dalam kegiatan belajar menjadikan pengalaman belajar lebih bermakna, sehingga keberhasilan dalam belajar dapat dicapai dan dituntaskan secara bersama-sama. Hal ini perlu dilakukan sebagaimana penelitian yang dilakukan Situmorang, dkk., bahwa model pembelajaran kooperatif tipe make a match dapat meningkatkan hasil belajar secara optimal (Situmorang, Purba, \& Gultom, 2021). Selain itu model pembelajaran kooperatif tipe make a match ini menjadi suatu model yang berorientasi pada permainan. Sehingga menjadian kegiatan belajar menjadi lebih menyenangkan (Faslia, 2021).

\section{METODE PENELITIAN}

Penelitian dilakukan di MTs Jam'iyyatul Khair, yang beralamat di jalan Wr. Supratman No. 35, Rt.002/06, Kelurahan Cempaka Putih, Ciputat Timur. Penelitian dilaksanakan pada bulan Februari 2012 di Semester Genap, Tahun Ajaran 2011-2012.

Metode penelitian menggunakan metode penelitian tindakan kelas model Kemmis dan Mc Taggart. Pelaksanaan penelitian tindakan ini mencakup empat langkah, yakni perencanaan, tindakan, observasi dan refleksi seperti yang dapat dijelaskan pada Gambar 2 (Kunandar, 2010). Adapun desain intervensi tindakan dapat dipaparkan pada Tabel 1. 


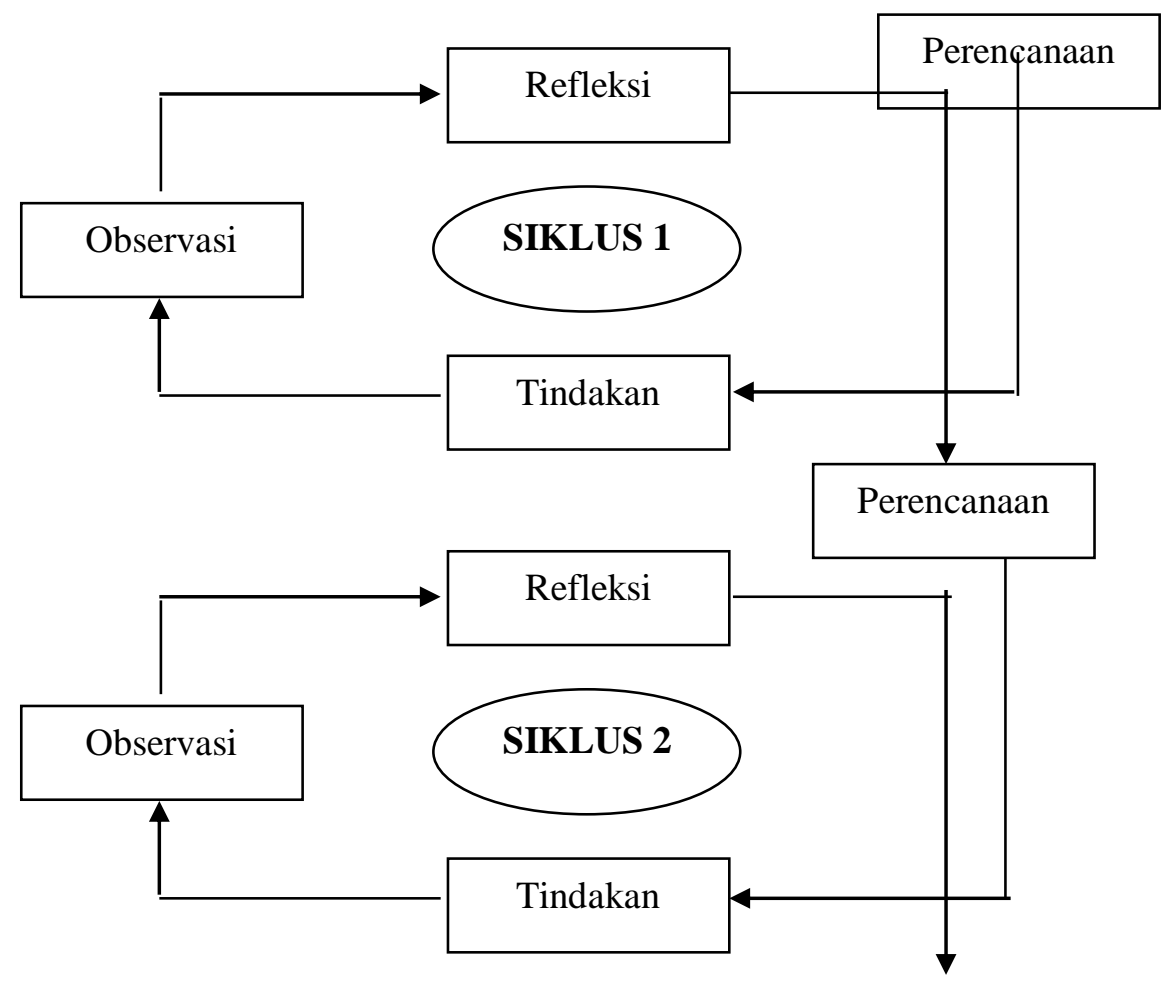

Gambar 2. Tahapan Penelitian Tindakan Kelas

Tabel 1. Desain Intervensi Tindakan

\begin{tabular}{|c|c|}
\hline Desain & Uraian \\
\hline Perencanaan Awal & $\begin{array}{l}\text { Mengetahui proses pembelajaran IPA-Biologi di sekolah yang dijadikan } \\
\text { tempat penelitian. }\end{array}$ \\
\hline Diagnosa & $\begin{array}{l}\text { Penerapan model pembelajaran kooperatif tipe make a match dapat } \\
\text { meningkatkan hasil belajar biologi. }\end{array}$ \\
\hline Temuan Awal & $\begin{array}{l}\text { Berdasarkan hasil observasi di dalam kelas dan wawancara terbuka dengan } \\
\text { guru, diperoleh keterangan bahwa dalam proses pembelajarannya, metode } \\
\text { ceramah lebih dominan. } \\
\text { Di MTs Jam'iyyatul Khair, kelas VII terbagi menjadi dua kelas, yakni VII-1 } \\
\text { dan VII-2. Kelas yang memiliki hasil belajar rendah adalah kelas VII-2, } \\
\text { apabila dibandingkan dengan kelas VII-1. }\end{array}$ \\
\hline Perencanaan & $\begin{array}{l}\text { 1. Merencanakan model pembelajaran yang akan diterapkan di kelas VII-2. } \\
\text { 2. Membuat rencana pelaksanaan pembelajaran (RPP) dan instrumen. }\end{array}$ \\
\hline Tindakan & $\begin{array}{l}\text { 1. Guru memberikan materi pelajaran sesuai materi yang telah disiapkan. } \\
\text { 2. Guru mengadakan kegiatan belajar mengajar dengan menerapkan model } \\
\text { pembelajaran kooperatif tipe make a match. }\end{array}$ \\
\hline Observasi & $\begin{array}{l}\text { 1. Mengumpulkan data penelitian. Data yang dikumpulkan berupa tes hasil } \\
\text { belajar. } \\
\text { 2. Mengolah dan menganalisis data yang diperoleh pada siklus } 1 \text {. }\end{array}$ \\
\hline Refleksi & $\begin{array}{l}\text { 1. Merujuk pada indikator pencapaian hasil (IPH) } \geq 80 \% \text { dan ketuntasan } \\
\text { kriteria minimal }(\mathrm{KKM}) \geq 70 \text {. } \\
\text { 2. Menarik kesimpulan dan merefleksikan kekurangan siklus } 1 \text { sebagai } \\
\text { pengembangan siklus selanjutnya. }\end{array}$ \\
\hline
\end{tabular}


577 Penerapan Model Pembelajaran Kooperatif Tipe Make A Match untuk Meningkatkan Hasil Belajar Biologi - Tri Suwarno Handoko Noviyanto, Baiq Hana Susanti, Siti Khairunnisa

DOI: https://doi.org/10.31004/edukatif.v4i1.1855

Sampel penelitian adalah siswa kelas VII-2 MTs Jam'iyyatul Khair pada Semester Genap Tahun Ajaran 2011-2012 yang berjumlah 17 siswa, yang terdiri atas 7 orang siswa laki-laki dan 10 orang siswa perempuan. Pada penelitian ini, peneliti berperan langsung dalam proses pembelajaran sebagai guru bidang studi.

Penelitian tindakan kelas ini dilaksanakan lebih dari satu siklus. Hal ini dimaksudkan untuk melihat peningkatan hasil belajar biologi pada setiap siklus setelah diberi tindakan. Bila pada siklus 1 terdapat perkembangan, maka penelitian pada siklus 2 lebih diarahkan pada perbaikan dan penyempurnaan terhadap hal-hal yang dianggap kurang pada siklus 1 .

Dalam penelitian ini, pengumpulan data dengan menggunakan tes. Tes berupa tes objektif yang berbentuk pilihan ganda, dengan 4 alternatif pilihan pada setiap butir, yaitu a, b, c dan d. Materi tes yang diberikan adalah materi pelestarian keanekaragaman hayati dan kepadatan populasi. Tes tersebut disusun berdasarkan ranah kognitif taksonomi Bloom, pada jenjang C1 (pengetahuan/hafalan), C2 (pemahaman) dan C3 (penerapan), yang dapat dideskripsikan dalam instrumen tes pada tabel 2. Tes berjumlah 20 butir soal yang dilakukan dua kali terhadap siswa di setiap siklusnya. Tes pertama diberikan kepada siswa sebelum dilakukannya pembelajaran (pretest) dan tes kedua diberikan kepada siswa setelah dilakukannya pembelajaran (posttest).

Tabel 2. Instrumen Tes

\begin{tabular}{|c|c|c|c|c|c|c|}
\hline \multicolumn{7}{|c|}{ Siklus 1} \\
\hline \multirow{2}{*}{$\begin{array}{l}\text { Kompetensi } \\
\text { Dasar }\end{array}$} & \multirow{2}{*}{$\begin{array}{c}\text { Pengembangan Indikator } \\
\text { dari Submateri }\end{array}$} & \multicolumn{3}{|c|}{ Jenjang Kognitif } & \multirow{2}{*}{ Jumlah } & \multirow{2}{*}{$\begin{array}{l}\text { Persen } \\
\text { tase }\end{array}$} \\
\hline & & C1 & $\mathrm{C2}$ & $\mathbf{C 3}$ & & \\
\hline \multirow{4}{*}{$\begin{array}{l}7.2 \\
\text { Mengidentifikas } \\
\text { i pentingnya } \\
\text { keanekaragaman } \\
\text { makhluk hidup } \\
\text { dalam } \\
\text { pelestarian } \\
\text { ekosistem }\end{array}$} & $\begin{array}{l}\text { Jenis tumbuhan dan hewan } \\
\text { Indonesia yang dilindungi }\end{array}$ & $1,5^{*}, 12$ & 7,30 & & 5 & $\begin{array}{c}16.67 \\
\%\end{array}$ \\
\hline & $\begin{array}{l}\text { Penyebab kelangkaan hewan } \\
\text { dan tumbuhan }\end{array}$ & $2 *$ & $\begin{array}{c}6^{*}, \mathbf{8}, \mathbf{1 3} \\
\mathbf{1 5}, 19^{*} \\
\mathbf{2 3}\end{array}$ & 29 & 8 & $\begin{array}{c}26.67 \\
\%\end{array}$ \\
\hline & $\begin{array}{l}\text { Usaha pelestarian } \\
\text { keanekaragaman hayati }\end{array}$ & $\begin{array}{l}3,14^{*} \\
25^{*}\end{array}$ & $\begin{array}{l}9^{*}, \mathbf{1 7} \\
\mathbf{2 0}, \mathbf{2 4}\end{array}$ & $\begin{array}{c}11^{*}, \mathbf{2 1} \\
\mathbf{2 8}\end{array}$ & 10 & $\begin{array}{c}33.33 \\
\%\end{array}$ \\
\hline & $\begin{array}{l}\text { Kawasan pelestarian } \\
\text { keanekaragaman hayati }\end{array}$ & $\begin{array}{c}\mathbf{4 , 1 0}, \\
16^{*}, 18^{*} \\
\mathbf{2 2}\end{array}$ & 26 & 27 & 7 & $\begin{array}{c}23.33 \\
\%\end{array}$ \\
\hline \multicolumn{2}{|r|}{ Jumlah } & 12 & 13 & 5 & 30 & \multirow{2}{*}{$100 \%$} \\
\hline \multicolumn{2}{|r|}{ Persentase } & $40 \%$ & $43.33 \%$ & $16.67 \%$ & $100 \%$ & \\
\hline \multicolumn{7}{|c|}{ Siklus 2} \\
\hline \multirow{2}{*}{$\begin{array}{l}\text { Kompetensi } \\
\text { Dasar }\end{array}$} & \multirow{2}{*}{$\begin{array}{c}\text { Pengembangan Indikator } \\
\text { dari Submateri }\end{array}$} & \multicolumn{3}{|c|}{ Jenjang Kognitif } & \multirow{2}{*}{ Jumlah } & \multirow{2}{*}{$\begin{array}{l}\text { Perse } \\
\text { ntase }\end{array}$} \\
\hline & & C1 & $\mathrm{C2}$ & $\mathbf{C 3}$ & & \\
\hline \multirow{6}{*}{$\begin{array}{l}7.3 \\
\text { Memprediksi } \\
\text { pengaruh } \\
\text { kepadatan } \\
\text { populasi } \\
\text { manusia } \\
\text { terhadap } \\
\text { lingkungan }\end{array}$} & Kepadatan populasi manusia & $2,3,5^{*}$ & \multicolumn{2}{|l|}{$12,30^{*}$} & 5 & $\begin{array}{c}16.67 \\
\%\end{array}$ \\
\hline & $\begin{array}{l}\text { Penyebab kepadatan populasi } \\
\text { manusia }\end{array}$ & $\begin{array}{c}1,13,16 \\
20,23\end{array}$ & $6^{*}, \mathbf{8}, 19$ & 29 & 9 & $30 \%$ \\
\hline & $\begin{array}{l}\text { Akibat kepadatan populasi } \\
\text { manusia }\end{array}$ & 25 & $\begin{array}{l}\mathbf{9}, 14^{*} \\
15^{*}, \mathbf{1 7} \\
28^{*}\end{array}$ & $\mathbf{1 1}, 21 *$ & 8 & $\begin{array}{c}26.67 \\
\%\end{array}$ \\
\hline & $\begin{array}{l}\text { Usaha mengatasi kepadatan } \\
\text { populasi manusia }\end{array}$ & $4 *$ & $\begin{array}{l}7,10,18 \\
22,\end{array}$ & $\begin{array}{c}24 *, \mathbf{2 6}, \\
27 *\end{array}$ & 8 & $\begin{array}{c}26.67 \\
\%\end{array}$ \\
\hline & Jumlah & 10 & 14 & 6 & 30 & $100 \%$ \\
\hline & Persentase & $33.33 \%$ & $46.67 \%$ & $20 \%$ & $100 \%$ & \\
\hline
\end{tabular}




\section{Keterangan:}

- $\quad(*)=$ Soal invalid

- Soal yang telah dinyatakan valid adalah hasil dari perhitungan validitas (biserial) dan validitas konstrak (revisi butir soal)

Analisis data dengan menggunakan rumus Gain-Ternormalisasi (N-Gain). Gain adalah selisih antara nilai posttest dan pretest, dan gain menunjukkan peningkatan pemahaman atau penguasaan konsep siswa setelah pembelajaran dilakukan oleh guru. Skor gain ternormalisasi menunjukkan tingkat efektivitas suatu perlakuan, yang dilihat dari hasil perolehan posttest. Terdapat tiga kriteria perolehan skor gain ternormalisasi, antara lain:

$$
\begin{aligned}
& \mathrm{N}-\text { Gain }=\frac{(\text { skor } \text { posttest } \text { - skor pretest })}{(\text { skor maksimal }- \text { skor pretest })} \\
& \text { Ket: } \text { g-tinggi } \quad: \text { nilai }(<\mathrm{g}>)>0,7 \\
& \text { g-sedang } \quad: \text { nilai } 0,7>(<\mathrm{g}>)>0,3 \\
& \text { g-rendah } \quad: \text { nilai }(<\mathrm{g}>)<0,3
\end{aligned}
$$

Adapun keberhasilan dalam belajar merujuk pada indikator pencapaian hasil (IPH) $\geq 80 \%$ dan nilai ketuntasan minimal $(\mathrm{KKM}) \geq 70$.

\section{HASIL DAN PEMBAHASAN PENELITIAN}

Berdasarkan data yang telah diperoleh peneliti, hasil pretest dan posttest pada siklus 1 memperlihatkan nilai pretest terendah adalah 30 dan tertinggi adalah 90, sementara nilai posttest terendah adalah 45 dan tertinggi adalah 90. Adapun secara keseluruhan rata-rata siklus 1 untuk pretest adalah 50,59, dan posttest adalah 68,82. Ketuntasan belajar pada siklus 1 , terdapat 10 siswa $(58,82 \%)$ yang sudah tuntas dan 7 siswa $(41,18 \%)$ yang belum tuntas. Dalam hal ini, belum tercapainya indikator pencapaian hasil (IPH $\geq 80 \%)$, karena pada siklus 1 sebesar 58,82\%. Hasil pretest yang diperoleh adalah murni kemampuan awal siswa. Setelah adanya fase tindakan, yang mana siswa diberikan kesempatan untuk mendapatkan pengetahuan dengan model yang diimplementasikan, menghasilkan nilai posttest yang lebih besar. Sebagaimana penelitian Artini,dkk., bahwa kelas yang diberikan model pembelajaran make a match memiliki motivasi belajar lebih baik dibanding dengan kelas pembelajaran konvensional (Artini, Adnyana, \& Warpala, 2019).

Adapun skor N-Gain untuk kriteria N-Gain tinggi sebanyak 0 siswa (0\%), sedang sebanyak 9 siswa $(52,94 \%)$ dan rendah sebanyak 8 siswa $(47,06 \%)$. Peningkatan hasil belajar juga belum memperlihatkan kriteria tinggi, dikarenakan hasil posttest tidak jauh berbeda dengan hasil pretest. Hal ini sejalan juga dengan penelitian Rokhanah, dkk., yang menjelaskan bahwa Siklus I belum memperlihatkan hasil tindakan yang optimal. Guru masih menemui kendala seperti belum berpartisipasinya semua siswa dalam pembelajaran di kelas. Oleh karena itu, peneliti dalam melaksanakan proses pembelajaran perlu lebih intensif dalam menerapkan kooperatif tipe make a match, agar adanya peningkatan hasil belajar pada siklus 2 (Rokhanah, Widowati, \& Sutanto, 2021). Bila perlu pengacakan kartu antar siswa dilakukan berulang kali dan saling berganti, sehingga pengalaman belajar yang didapat akan lebih banyak.

Pada siklus 2, peneliti melakukan pembelajaran make a match secara lebih optimal. Berdasarkan data yang diperoleh bahwa nilai pretest terendah adalah 15 dan tertinggi adalah 60 . Sementara nilai posttest terendah adalah 55 dan tertinggi 95. Adapun secara keseluruhan rata-rata siklus 2 untuk pretest adalah 41,47, dan posttest adalah 83,53. Untuk ketuntasan belajar pada siklus 2, terdapat 15 siswa $(88,24 \%)$ yang sudah tuntas dan 2 siswa $(11,76 \%)$ yang belum tuntas. Dalam hal ini, walaupun ada beberapa siswa yang belum tuntas, namun indikator pencapaian hasil (IPH) sudah melebihi $80 \%$, yakni sebesar 88,24\%. 
Dari hasil siklus 2 tersebut, mengacu pada penelitian yang dilakukan oleh Ermita, memaparkan bahwa penggunaan make a match dapat dipertimbangkan sebagai model pembelajaran yang tepat untuk meningkatkan keaktifan. Sekalipun hasil dari posttest seluruh siswa tidak seratus persen mencapai KKM, namun proses pembelajaran terbangun dengan penuh perhatian, bimbingan, dan motivasi dari guru dan antar siswa. Dengan begini siswa yang masih pasif menjadi terlibat untuk mencari kartu pasangan yang sesuai dengan yang siswa tersebut miliki.Secara prinsip, apabila siswa memahami apa yang mereka pelajari dengan model ini, maka siswa tidak akan mengalami kesulitan di saat posttest. Dan hal tersebut nyatanya terbukti, bahwa secara keseluruhan siswa telah mencapai IPH (Ermita, 2021).

Adapun skor N-Gain untuk kriteria N-Gain tinggi sebanyak 12 siswa (70,59\%), sedang sebanyak 5 siswa $(29,41 \%)$ dan rendah 0 siswa $(0 \%)$. Peningkatan hasil belajar sangat signifikan bila dibandingkan dengan siklus 1, dikarenakan banyak siswa yang mendapatkan kriteria N-Gain tinggi. Hal tersebut menjadi capaian di siklus 2 . Hal ini senada dengan penekitian Wahyudin yang menjelaskan bahwa ada peningkatan perolehan ketercapaian dari siklus I ke siklus II. Hal ini tentunya merupakan hasil dari intensifnya peneliti untuk memacu semangat belajar siswa agar pada siklus II mengalami kenaikan yang signifikan (Wahyudin, 2020).

Berdasarkan hasil penelitian yang telah dilakukan, bahwa pembelajaran kooperatif tipe make a match dapat meningkatkan hasil belajar siswa. Hal ini ditunjukkan dengan adanya peningkatan nilai rata-rata tes hasil belajar dari siklus 1 ke siklus 2. Jika dilukiskan dalam bentuk grafik, peningkatan rata-rata nilai posttest untuk siklus 1 dan 2 dapat dijelaskan pada gambar 3. Melihat data tersebut, penelitian ini sejalan dengan penelitian dari Purwanti dan Saputri, yang menjelaskan bahwa model pembelajaran kooperatif tipe make a match sangat efektif dalam meningkatkan hasil belajar IPA (Purwanti \& Saputri, 2020).

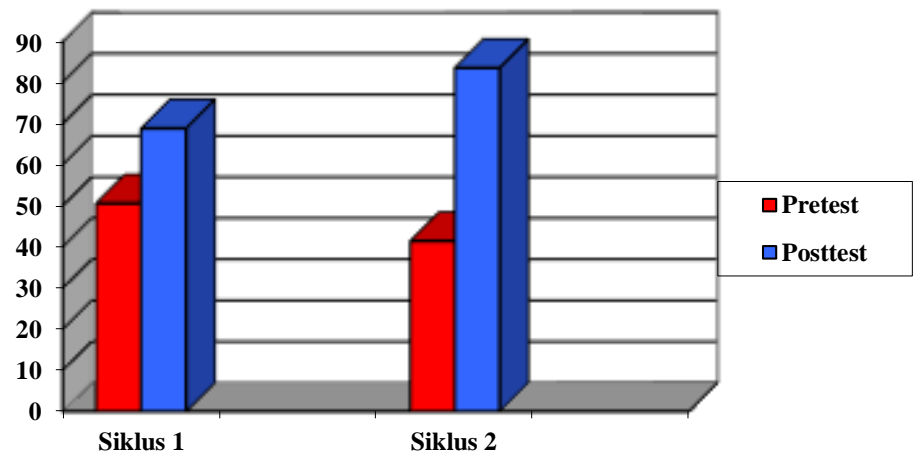

Gambar 3. Grafik Peningkatan Rata-rata Nilai Posttest Siklus 1 dan 2

Jika mengobservasi siklus 2, bahwa masih terdapat beberapa siswa yang belum memenuhi ketuntasan belajar, karena nilai posttest beberapa siswa tersebut belum mencapai KKM, yakni 70. Kenyataan ini tidak bisa dihindari bahwa terdapat banyak faktor sebagai pengganggu yang tidak bisa dikontrol. Akan tetapi, hal ini tetap memperlihatkan sebuah keberhasilan bahwa pembelajaran kooperatif tipe make a match mampu meningkatkan hasil belajar siswa, dikarenakan indikator pencapaian hasil (IPH) pada siklus 2 sudah di atas $80 \%$, yakni $88,24 \%$. Sebagaimana penelitian Fauhah dan Rosy, menjabarkan bahwa pembelajaran make a match dapat direkomendasikan sebagai model pembelajaran kooperatif yang bermanfaat untuk pengembangan kualitas diri dalam belajar dan mencari atau menerima informasi dari siswa lain (Fauhah \& Rosy, 2021).

Keberhasilan siswa untuk meningkatkan hasil belajarnya, dipengaruhi oleh faktor dari diri siswa (internal) maupun faktor dari luar diri siswa (eksternal). Faktor dari dalam seperti timbulnya minat dan kemauan yang tinggi untuk meningkatkan hasil belajar yang dinilai masih rendah. Faktor dari luar bisa disebabkan dari cara guru menciptakan suasana pembelajaran. Dalam pembelajaran biologi dibutuhkan 
keaktifan sebagai dasar untuk pengembangan materi lebih lanjut, dan hal ini sangat dipengaruhi oleh faktor model pembelajaran yang digunakan. Pembelajaran yang pasif akan menghambat kreatifitas serta pola pikir siswa dalam memahami suatu konsep. Oleh karena itu, dalam proses pembelajaran biologi siswa dituntut benar-benar aktif, sehingga daya ingat siswa tentang apa yang telah dipelajari akan lebih baik. Proses belajar mengajar biologi yang baik adalah guru harus mampu menerapkan suasana yang dapat membuat siswa antusias terhadap persoalan yang ada, sehingga mereka mampu untuk mencoba memecahkan persoalan tersebut. Guru perlu membantu mengaktifkan siswa untuk berpikir (Topandra \& Hamimah, 2020).

Penerapan model pembelajaran kooperatif tipe make a match, memperlihatkan beberapa temuan bahwa model ini dapat memupuk kerja sama siswa dalam menjawab pertanyaan dengan mencocokkan kartu yang didapat oleh setiap siswa. Proses pembelajaran make a match terkesan lebih menarik dan tampak sebagian besar siswa lebih antusias mengikuti proses pembelajaran (Aliputri, 2018).

Berdasarkan analisa di atas, dapat dikatakan model pembelajaran kooperatif tipe make a match memberikan banyak manfaat bagi siswa, di antaranya mampu menciptakan suasana belajar aktif dan menyenangkan, materi pembelajaran yang disampaikan menjadi lebih menarik, serta mampu meningkatkan hasil belajar siswa. Namun, seiring dengan perkembangan kemajuan bidang keilmuan pendidikan bahwa penelitian ini masih terbatas pada dua variabel yang mana sudah tidak relevan dengan tuntutan jaman yang ada. Oleh karenanya, referensi dan inovasi dalam penelitian perlu terus dipupuk dan diperbaharui seiring perkembangan jaman dari waktu ke waktu.

\section{KESIMPULAN}

Penelitian tindakan kelas yang dilakukan di MTs Jam'iyyatul Khair, disimpulkan bahwa penerapan model pembelajaran kooperatif tipe make a match dapat meningkatkan hasil belajar biologi. Hal ini terlihat dari persentase pencapaian KKM di siklus 2 sebesar 88,24\%, yang mana sudah mencapai indikator pencapaian hasil (IPH) $\geq 80 \%$. Dalam praktik pembelajaran make a match, sebaiknya menggunakan banyak kartu pertanyaan, agar siswa lebih terlatih untuk mengembangkan kemampuan berpikir. Selain itu, meminta alasan kepada siswa juga lebih diintensifkan, agar siswa lebih terbiasa dalam mengemukakan pendapat dan melatih rasa tanggung jawab.

\section{UCAPAN TERIMA KASIH}

Penulis menyadari bahwa penulisan jurnal ini tidak terlepas dari bantuan pihak-pihak terkait. Oleh karenanya, penulis ingin mengucapkan terima kasih kepada tim dosen Pendidikan Biologi, dan tim guru MTs Jam'iyyatul Khair.

\section{DAFTAR PUSTAKA}

Aliputri, D. H. (2018). Penerapan Model Pembelajaran Kooperatif Tipe Make A Match Berbantuan Kartu Bergambar Untuk Meningkatkan Hasil Belajar Siswa. Jurnal Bidang Pendidikan Dasar, 70-77.

Artini, R. J., Adnyana, P. B., \& Warpala, I. W. (2019). Pengaruh Model Pembelajaran Make A Match Berbantuan Media Couple Card Terhadap Motivasi Belajar dan Hasil Belajar Biologi Materi Sistem Ekskresi pada Manusia Siswa Kelas XI SMA Negeri 2 Banjar. Jurnal Pendidikan Biologi Undiksha, 3343.

Budiarti, I. S., Suparmi, A., Sarwanto, \& Harjana. (2020). Effectiveness of Generation, Evaluation, and Modification-Cooperative Learning (Gem-CL) Model Selaras Bakar Batu Cultural Practice in Papua. Jurnal Pendidikan IPA Indonesia, 32-41. doi:https://doi.org/10.15294/jpii.v9i1.22362 
581 Penerapan Model Pembelajaran Kooperatif Tipe Make A Match untuk Meningkatkan Hasil Belajar Biologi - Tri Suwarno Handoko Noviyanto, Baiq Hana Susanti, Siti Khairunnisa

DOI: https://doi.org/10.31004/edukatif.v4i1.1855

Devi, A. D., \& Subiyantoro. (2021). Implementasi Manajemen Berbasis Sekolah dalam Meningkatkan Kualitas di Sekolah Menengah Pertama. Edukatif: Jurnal Ilmu Pendidikan, 963-971. doi:https://doi.org/10.31004/edukatif.v3i3.481

Ermita. (2021). Make a Match: Sebuah Metode untuk Meningkatkan Keaktifan. Jurnal Studi Guru dan Pembelajaran, 429-436. doi:https://doi.org/10.30605/jsgp.4.2.2021.1286

Faslia. (2021). Meningkatkan Hasil Belajar Siswa Pada Mata Pelajaran IPS Melalui Model Pembelajaran Make A Match di Sekolah Dasar. Edukatif: Jurnal Ilmu Pendidikan, 2071-2078. doi:https://doi.org/10.31004/edukatif.v3i5.740

Fauhah, H., \& Rosy, B. (2021). Analisis Model Pembelajaran Make A Match Terhadap Hasil Belajar Siswa. Jurnal Pendidikan Administrasi Perkantoran, 321-334 .

Hadiyanti, A. H. (2021). Pengembangan Media Kartu Permainan IPA untuk Perkuliahan IPA Biologi. Edukatif: Jurnal Ilmu Pendidikan, 4356-4362. doi:https://doi.org/10.31004/edukatif.v3i6.1336

Kunandar. (2010). Langkah Mudah Penelitian Tindakan Kelas sebagai Pengembangan Profesi Guru. Jakarta: PT. Rajawali Pers.

Mulyasa, E. (2008). Kurikulum Tingkat Satuan Pendidikan. Bandung: Remaja Rosdakarya.

Purwanti, S., \& Saputri, N. D. (2020). Efektivitas Model Cooperative Learning Tipe Make A Match Terhadap Hasil Belajar IPA pada Siswa Kelas V SD Muhammadiyah Karangploso. Jurnal Taman Cendekia, 445451.

Ramadhani, M. I. (2021). Peningkatan Hasil Belajar IPS menggunakan Model Pembelajaran Make A Match pada Siswa Sekolah Dasar. Edukatif: Jurnal Ilmu Pendidikan, 2237-2244. doi:https://doi.org/10.31004/edukatif.v3i4.1159

Riyanto, Y. (2009). Paradigma Baru Pembelajaran: Sebagai Referensi bagi Guru Pendidik dalam Implementasi Pembelajaran yang Efektif dan Berkualitas. Jakarta: Kencana.

Rokhanah, N., Widowati, A., \& Sutanto, E. H. (2021). Peningkatan Keaktifan Belajar Siswa dengan Menerapkan Model Pembelajaran Kooperatif Tipe Student Team Achievement Divisions (STAD). Edukatif: Jurnal Ilmu Pendidikan, 3173-3180. doi:https://doi.org/10.31004/edukatif.v3i5.860

Sabariah. (2022). Manajemen Sekolah dalam Meningkatkan Mutu Pendidikan. Edukatif: Jurnal Ilmu Pendidikan, 116-122. doi:https://doi.org/10.31004/edukatif.v4i1.1764

Sanjaya, W. (2008). Strategi Pembelajaran Berorientasi Standar Proses Pendidikan. Jakarta: Kencana.

Situmorang, M. V., Purba, N., \& Gultom, B. T. (2021). Implementasi Model Pembelajaran Kooperatif Make A Match (MAM) dalam Peningkatan. Edukatif: Jurnal Ilmu Pendidikan, 4041-4048. doi:https://doi.org/10.31004/edukatif.v3i6.1286

Sukmadinata, N. S. (2007). Landasan Psikologi Proses Pendidika. Bandung: Remaja Rosdakarya.

Topandra, M., \& Hamimah. (2020). Model Kooperatif Tipe Make A Match dalam Pembelajaran Tematik Terpadu di Sekolah Dasar. Jurnal Pendidikan Tambusai, 1256-1268.

Wahyudin, U. (2020). Penerapan Model Skrip Kooperatif pada Mata Pelajaran Ilmu Pengetahuan Sosial. Jurnal Educatio, 119-124. doi:https://doi.org/10.31949/educatio.v6i1.284

Wandra, D., Marsyidin, S., \& Rifma. (2021). Peranan Supervisi Pengawas Madrasah dalam Meningkatkan Mutu Pendidikan. Edukatif: Jurnal Ilmu Pendidikan, 3647-3653. doi:https://doi.org/10.31004/edukatif.v3i6.977

Zulfiani, Feronika, T., \& Suartini, K. (2009). Strategi Pembelajaran Sains. Jakarta: Lembaga Penelitian UIN Jakarta. 